\title{
Langtidsbivirkninger av antiepileptika
}

\author{
I Norge bruker rundt 120000 mennesker antiepileptika daglig. Bruken \\ har $ø$ kt de senere årene, delvis fordi disse legemidlene også benyttes \\ ved psykiske lidelser, migrene og nevropatiske smerter. Behandlingen \\ varer som regel mange år. Det er viktig å gjøre seg kjent med lege- \\ midlenes bivirkningsprofil, spesielt fordi langtidsbivirkningene gjerne \\ kommer snikende og er lette å overse for både lege og pasient.
}

Epilepsi kan ha svært forskjellig alvorlighetsgrad, men mange pasienter trenger medikamentell behandling over flere år. Derfor er det viktig å vite om medikamentene kan gi bivirkninger på kort og/eller lang sikt.

Noen bivirkninger kan være vanskelig å skille fra selve epilepsien eller anfallene, og noen pasienter har komorbide tilstander som gir lignende symptomer. De kroniske legemiddelbivirkningene kommer gjerne snikende og er ikke alltid lette å identifisere verken for lege eller pasient. Noen av bivirkningene er reversible når legemidlet seponeres, selv etter langtidsbruk. Andre er varige (1).

For å fange opp langtidsbivirkninger bør alle pasienter som bruker antiepileptika ha minst én årlig kontakt med lege. Ved denne kontakten bør oppmerksomheten rettes ikke bare mot anfallssituasjonen, men også mot mulige legemiddelbivirkninger og hvordan disse eventuelt påvirker pasienten i dagliglivet. I noen tilfeller finnes det tiltak som til en viss grad kan forebygge bivirkninger.

Hensikten med denne artikkelen er å gi en kort oversikt over de vanligst forekommende bivirkningene knyttet til langtidsbruk av antiepileptika og gi råd om forebyggende behandling, der slik finnes. I teksten er bivirkningene gruppert etter hvilke organsystemer eller vev som affiseres, mens tabell 1 viser de hyppigste bivirkningene knyttet til hvert enkelt legemiddel.

Artikkelen bygger på relevante engelskspråklige oversiktsartikler funnet i PubMed i tillegg til forfatternes egne litteraturarkiv og kliniske erfaring.

\section{Hjerte- og karsykdom}

Enzyminduserende antiepileptika, dvs. de som induserer cytokrom P-450-enzymsystemet i leveren, spesielt fenobarbital, fenytoin og karbamazepin, er ved langvarig bruk vist å øke risikoen for utvikling av aterosklerose (2). Denne effekten skyldes sannsynligvis disse enzymenes rolle i syntesen av kolesterol. De nevnte legemidlene fører til en ugunstig endring av lipidprofilen. De er også folatantagonister, og lave folatnivåer er assosiert med hyperhomocysteinemi som er vist å øke risikoen for aterosklerose.

Ved å indusere hyperinsulinemi, dyslipidemi, forhøyede verdier av urinsyre og homocystein samt fedme kan valproat, som er en enzyminhibitor, også gi økt risiko for hjerte-og karsykdom.

Karbamazepin kan gi hjertearytmier, spesielt hos dem med atrioventrikulær ledningsforstyrrelse. Hos pasienter med forlenget QT-intervall bør man unngå fenytoin, karbamazepin, lamotrigin og retigabin, som alle kan forlenge dette intervallet ytterligere (3).

EKG bør tas før oppstart med antiepileptika som kan gi arytmier. Før man setter inn et enzyminduserende antiepileptikum hos pasienter med hjertesykdom, bør man gjøre en grundig risiko-nytte-vurdering.

\section{Psykiske og kognitive bivirkninger}

Antiepileptika kan gi tretthet og redusert psykomotorisk tempo. Fenobarbital, topiramat og zonisamid gir økt risiko for kognitive vansker. Disse har også, sammen med levetiracetam, høyere risiko for psykiske bivirkninger som depresjon, psykolabilitet m.m. $(1,2,4)$.

Enkelte andre antiepileptika, som lamotrigin, valproat og karbamazepin, kan ha positive psykotrope effekter og blir i dag benyttet $\mathrm{i}$ behandlingen av psykiske lidelser.

Hos pasienter med en psykiatrisk sykehistorie eller som tidligere har reagert med psykiske bivirkninger, bør man forsøke å unngå antiepileptika med negative psykotrope egenskaper. Der det ikke er andre gode behandlingsalternativer bør pasientene følges tett for å fange opp slike bivirkninger.

\section{Teratogene effekter}

De siste årene har vi fått bedre dokumentasjon på risikoen for fosterskadelige effekter av antiepileptikabruk i svangerskapet. Størst risiko knytter det seg til bruk av høye doser av valproat, fenobarbital og topiramat, og disse preparatene bør helst unngås hos fertile kvinner $(1,5)$. Dersom andre behandlingsalternativer ikke gir tilfredsstillende

\author{
Torleiv Svendsen \\ torleiv.svendsen@ous-hf.no \\ Kristin Å. Alfstad \\ Morten I. Lossius \\ Karl 0. Nakken \\ Spesialsykehuset for epilepsi (SSE) \\ Klinikk for kirurgi og nevrofag \\ Oslo universitetssykehus
}

\section{HOVEDBUDSKAP}

Ved oppfølging av pasienter som bruker antiepileptika er det viktig å gjøre seg kjent med legemidlenes bivirkningsprofil

Det er ulik risiko for bivirkninger avhengig av alder, kjønn og individuelle sårbarhetsfaktorer

Fordi bivirkningene kommer snikende over år, blir de lett oversett 
anfallskontroll, bør lavest mulig dose benyttes. I tillegg anbefales tilskudd av $4 \mathrm{mg}$ folat daglig prekonsepsjonelt og gjennom første trimester samt tett oppfølging før og under graviditeten.

\section{Endokrinologiske bivirkninger}

Enzyminduserende antiepileptika kan påvirke steroidhormoner og sexhormonbindende globulin, noe som kan gi hypogonadisme med reduserte nivåer av østradiol, progesteron og testosteron (6). Hos kvinner kan dette resultere i menstruasjonsforstyrrelser. Hos begge kjønn kan disse legemidlene gi seksuell dysfunksjon og redusert fertilitet. Positivt er det at selv etter langtidsbruk ser slike forstyrrelser ut til å være reversible, i hvert fall når det gjelder karbamazepin.

Hos kvinner som bruker valproat er det sett øt forekomst av hyperandrogenisme, polycystiske ovarier, polycystisk ovarie-syndrom (PCOS), menstruasjonsforstyrrelser og infertilitet (7). Polycystisk ovarie-syndrom er assosiert med overvekt, glukoseintoleranse, hyperinsulinemi og dyslipidemi. Disse forstyrrelsene er i noen grad reversible etter seponering.

Valproat bør unngås til unge fertile kvinner, særlig om de samtidig er overvektige og har menstruasjons- og fertilitetsproblemer. Dersom slike problemer skulle oppstå under valproatbehandling, bør man vurdere å skifte til et annet legemiddel, eventuelt henvise til en endokrinologisk og gynekologisk undersøkelse.

\section{Kroppsvekt}

Hos personer som bruker valproat er det $ø \mathrm{kt}$ risiko for vektøkning. Vigabatrin, gabapentin, pregabalin, karbamazepin, levetiracetam og retigabin er også assosiert med lett vektoppgang, men i mindre grad enn ved bruk av valproat (8). Hos valproat kan vektøkningen skyldes hyperinsulinemi og/eller økt appetitt.

Topiramat gir vektnedgang hos $60-85 \%$, særlig uttalt blant overvektige. Zonisamid, felbamat, rufinamid og stiripentol kan også gi vekttap (2).

Ved all farmakologisk epilepsibehandling bør man ha oppmerksomheten rettet mot vektendringer hos pasientene. Veiledningssamtaler med ernæringsfysiolog kan være nyttig for mange.

\section{Skjelettet}

Hos personer som bruker enzyminduserende antiepileptika (som fenobarbital, fenytoin og karbamazepin), i noen grad også valproat, er det funnet lavere bentetthet og økt risiko for frakturer sammenlignet med den generelle befolkningen. Mekanismene bak antiepileptikas påvirkning på skjelettet er

Tabell 1 Et utvalg av langtidsbivirkninger knyttet til de mest brukte antiepileptika

\begin{tabular}{|c|c|}
\hline Antiepileptika & Potensielle langtidsbivirkninger \\
\hline Fenobarbital & $\begin{array}{l}\text { Tretthet, atferdsproblemer hos barn, redusert kognisjon, depresjon, } \\
\text { Dupuytrens kontraktur, redusert libido, folatmangel, osteoporose }\end{array}$ \\
\hline Fenytoin & $\begin{array}{l}\text { Gingival hyperplasi, hirsutisme, grove ansiktstrekk, folatmangel, cerebello- } \\
\text { pati, perifer nevropati, osteoporose, depresjon, redusert libido }\end{array}$ \\
\hline Karbamazepin & $\begin{array}{l}\text { Leukopeni, hyponatremi, osteoporose, kardiale rytmeforstyrrelser, seksuell } \\
\text { dysfunksjon, ødemer }\end{array}$ \\
\hline Okskarbazepin & Hyponatremi, osteoporose \\
\hline Valproat & $\begin{array}{l}\text { Vektøkning, hårtap, tremor, endokrine forstyrrelser, lever- eller pancreas- } \\
\text { skade, trombocytopeni, teratogene effekter }\end{array}$ \\
\hline Vigabatrin & Irreversible synsfeltsinnskrenkninger, vektøkning, psykose \\
\hline Lamotrigin & Søvnløshet \\
\hline Topiramat & $\begin{array}{l}\text { Vekttap, kognitive problemer, inkludert ordfinningsvansker, depresjon, } \\
\text { psykolabilitet, nyrestein, akroparestesier, hypohidrose }\end{array}$ \\
\hline Gabapentin & Vektøkning \\
\hline Levetiracetam & Irritabilitet, aggresjon, atferdsproblemer, vektøkning \\
\hline Pregabalin & Vektøkning \\
\hline Felbamat & Aplastisk anemi, hepatotoksisitet \\
\hline Zonisamid & $\begin{array}{l}\text { Vekttap, nyrestein, irritabilitet, mental treghet, ordfinningsvansker, hypo- } \\
\text { hidrose }\end{array}$ \\
\hline Etosuksimid & Psykose, hikke, bloddyskrasier \\
\hline Klobazam & Tretthet, atferdsforstyrrelser, sikling \\
\hline Eslikarbazepin & Hyponatremi \\
\hline Lakosamid & $\emptyset k t$ PR-intervall i EKG \\
\hline Perampanel & Irritabilitet, vektøkning \\
\hline Retigabin & Blålig misfarging av hud og negler, pigmentforandringer i retina \\
\hline
\end{tabular}

ikke fullt ut forstått, men påvirkning av Dvitaminmetabolismen, kalsiumnivået $\mathrm{og} /$ eller en direkte effekt på bencellene har vært postulert (9).

Hos pasienter som bruker disse legemidlene, og særlig hos dem som i tillegg har økt risiko for osteoporose (blant annet de med høy alder, lav kroppsmasseindeks (BMI) eller ensidig kosthold, postmenopausale kvinner, røykere, fysisk inaktive m.m.) anbefaler vi ekstra tilskudd av vitamin D (800 IE/dag), kalsium (1 $000 \mathrm{mg} / \mathrm{dag}$ ) og bentetthetsmåling hver 2-3 år. Påvises osteoporose eller pasienten har hatt lavenergibrudd, bør man gi bifosfonat, eventuelt bør man henvise pasienten til en endokrinolog.

\section{Fordøyelsessystemet}

På grunn av enzyminduksjonen gir særlig fenytoin, fenobarbital og karbamazepin en lett økning av leverenzymene (aspartataminotransferase, alaninaminotransferase, gam- maglutamyltransferase) i blodet. Dette gir ingen grunn til bekymring så sant verdiene ikke overstiger 2-3 ganger normalverdiene.

Leverpatologi kan forekomme ved bruk av de eldre antiepileptika. Ikke-alkoholisk fettlever kan ses ved bruk av valproat, i mindre grad også karbamazepin. Både valproat og felbamat kan i sjeldne tilfeller gi alvorlig leversvikt (2). Valproatbetinget hepatotoksisitet ses særlig hos pasienter med mitokondriesykdom og hos multifunksjonshemmede barn under to år som bruker kombinasjonsterapi (10).

\section{Hematologiske bivirkninger}

Karbamazepin er hos 10-20\% forbundet med en lettgradig leukopeni som bare sjelden gir grunn til dosereduksjon eller seponering (2). Valproat gir trombocytopeni hos rundt $20 \%$, men bare rundt $15 \%$ av disse får blødningstendens. Også levetiracetam kan gi trombocytopeni. 
Felbamat, i mindre grad også karbamazepin, fenytoin, fenobarbital og valproat, kan i sjeldne tilfeller gi aplastisk anemi, vanligvis i løpet av de første seks månedene etter behandlingsstart (1).

Særlig enzyminduserende antiepileptika kan gi folatmangel og dermed forårsake mild makrocytose. Megaloblastanemi er sjeldnere.

Slike hematologiske avvik kan fanges opp ved blodprøvekontroller.

\section{Hud, hår og tenner}

Gingival hyperplasi med økt risiko for karies er den mest kjente langtidsbivirkningen av fenytoin. Det kan ses allerede etter få måneders bruk og er særlig uttalt blant utviklingshemmede. Også karbamazepin, valproat og fenobarbital gir økt tendens til vekst av tannkjøttet, men i mindre grad enn fenytoin. Gingival hyperplasi kan til en viss grad forebygges ved godt tannstell og bruk av tannpirker/tanntråd.

På grunn av en svak antikolinerg effekt kan karbamazepin og gabapentin gi munntørrhet, noe som øker risikoen for karies.

Flere antiepileptika kan forårsake hirsutisme, akne, endret hårstruktur, hårtap eller alopesi. Vanligst er dette ved bruk av fenytoin og valproat. Fenytoin kan etter mange års bruk også gi et akromegalt utseende med blant annet grove ansiktstrekk.

\section{Bindevev}

Fenobarbital og primidon kan etter langvarig bruk gi «barbituratrevmatisme». Det ytrer seg særlig som Dupuytrens kontraktur og plantar fibromatose (Ledderhoses sykdom) (11).

\section{Urinveier}

Antiepileptika som hemmer karbonanhydrase, slike som topiramat, zonisamid, acetazolamid og sultiam gir en lett metabolsk acidose. Det disponerer for nyrestein (kalsiumfosfatsteiner). Dette ses hos $1-3 \%$ av pasientene (2). Hos dem som tidligere har hatt nyrestein bør man forsøke å unngå disse legemidlene.

\section{Elektrolytter}

Okskarbazepin og eslikarbazepin, i noen grad også karbamazepin, kan gi hyponatremi. Problemet er mest uttalt blant eldre. Hyponatremien er som regel asymptomatisk, men dette bør følges opp regelmessig, da mer alvorlige former (natrium i serum $<125 \mathrm{mmol} / \mathrm{l}$ ) forekommer hos opp til 2-3\% (12).

Ekstra salttilskudd ser ikke ut til å ha noen effekt, og ved alvorlig hyponatremi bør dosereduksjon eller seponering overveies.

\section{Syn}

Vigabatrin gir hos rundt $40 \%$ irreversible, konsentriske synsfeltsutfall, muligens på grunn av en toksisk effekt av GABA på retinale celler og et redusert taurinnivå. Ved bruk av dette preparatet bør pasientene følges av øyelege hver 6 . måned.

Som karbonanhydrasehemmer gir topiramat $ø$ kt risiko for glaukomutvikling. Pasienter som på dette preparatet rapporterer om tåkesyn eller sterke smerter i øyet, bør snarest henvises til øyelege (1).

Retigabin kan gi varige pigmentforandringer på retina $(2)$.

\section{Nevrologiske bivirkninger}

Fenytoin kan etter flere års bruk gi gangataksi med atrofi av cerebellum.

Langvarig bruk av fenytoin, i mindre grad også karbamazepin, kan dessuten gi sensorimotorisk distal polynevropati.

Karbonanhydrasehemmerne, spesielt topiramat, kan gi plagsomme distale parestesier.

Valproat kan, særlig ved høye serumkonsentrasjoner, gi en tremor som klinisk minner om benign essensiell tremor. Hos eldre kan valproat dessuten gi opphav til en reversibel parkinsonisme. I sjeldne tilfeller kan valproat også forårsake en metabolsk encefalopati på grunn av hyperammonemi. Tilstanden er reversibel (13).

Mens de fleste antiepileptika, spesielt de eldre, kan ha sederende effekt, kan lamotrigin og felbamat tvert om gi søvnløshet. Ved bruk av lamotrigin kan man unngå dette problemet ved å gi preparatet som monodose om morgenen.

\section{Diskusjon}

I all epilepsibehandling må man sammen med pasient og pårørende foreta en grundig risiko-nytte-vurdering. I en engelsk studie oppga nesten halvparten av pasientene å ha bivirkninger, og hos rundt $20 \%$ var disse så alvorlige at det medførte seponering (14). Bivirkninger av antiepileptika er vist å kunne påvirke epilepsipasienters livskvalitet mer enn anfallsfrekvensen (15).

Etter 1993 er det i Norge blitt markedsført 15 antiepileptiske legemidler med til dels nye virkningsmekanismer. Det kan i dag se ut til at flere av disse har en bedre bivirkningsprofil enn de gamle (fenobarbital, fenytoin, karbamazepin og valproat). De gamles påvirkning av leverenzymene gir ikke bare hyppige bivirkninger, men også økt risiko for farmakokinetiske interaksjoner med andre legemidler (1). Samtidig er det viktig å huske at det tok mange år for man ble klar over enkelte langtidsbivirkninger av de eldre preparatene. Allerede nå ser vi at noen av de nye er i stadig mindre bruk etter hvert som det er kommet rapporter om langtidsbivirkninger. Det gjelder spesielt felbamat, vigabatrin og retigabin, i noen grad også topiramat.

De patofysiologiske mekanismene bak bivirkningene er til dels ukjente. Noen pasienter er mer sårbare for utvikling av bivirkninger enn andre. Kanskje vil farmakogenetiske metoder kunne avdekke årsaker til dette i fremtiden.

Det er viktig å ta hensyn til bivirkningsprofilen ved valg av et antiepileptikum. Behandlingen bør tilpasses den enkelte pasient. Høye doser og multifarmasi gir særlig høy risiko for bivirkninger og krever en nøye avveining mot anfallsbelastningen.

\section{Torleiv Svendsen (f. 1962)}

er spesialist i nevrologi, med spesialkompetanse innen epileptologi, og er overlege ved Spesialsykehuset for epilepsi og ved Nevrologisk avdeling, Sykehuset Innlandet.

Forfatter har fylt ut ICMJE-skjemaet og oppgir følgende interessekonflikter: Han har mottatt forelesningshonorar fra Eisai, GSK, UCB Pharma og Novartis.

\section{Kristin Å. Alfstad (f. 1966)}

er spesialist i nevrologi og overlege. Hun arbeider med et doktorgradsprosjekt om psykiatrisk komorbiditet og kognitiv svikt hos barn og ungdom med epilepsi.

Forfatter har fylt ut ICMJE-skjemaet og oppgir ingen interessekonflikter.

\section{Morten I. Lossius (f. 1962)}

er dr.med., spesialist i nevrologi og overlege. Han er leder av forskningsgruppen «kompleks epilepsi» ved Oslo universitetssykehus.

Forfatter har fylt ut ICMJE-skjemaet og oppgir følgende interessekonflikter: Han har mottatt honorar for et læringsprogram for nevrologer fra UCB Pharma og har sittet i et ekspertpanel for Eisai.

\section{Karl O. Nakken (f. 1945)}

er spesialist i nevrologi, med spesialkompetanse i epileptologi, og er medisinsk sjef ved Avdeling for kompleks epilepsi.

Forfatter har fylt ut ICMJE-skjemaet og oppgir følgende interessekonflikter: Han har mottatt forelesningshonorar fra Eisai, GSK og UCB Pharma.

Litteratur

1. Perucca P, Gilliam FG. Adverse effects of antiepileptic drugs. Lancet Neurol 2012; 11: 792-802.

2. Gaitatzis A, Sander JW. The long-term safety of antiepileptic drugs. CNS Drugs 2013; 27: 435-55.

3. Saetre E, Abdelnoor M, Amlie JP et al. Cardiac function and antiepileptic drug treatment in the elderly: a comparison between lamotrigine and sustained-release carbamazepine. Epilepsia 2009 50: $1841-9$

4. Mula M, Monaco F. Antiepileptic drugs and psychopathology of epilepsy: an update. Epileptic Disord 2009; 11: 1-9.

5. Tomson T, Battino D, Bonizzoni E et al. Dosedepent risk of malformations with antiepileptic drugs: an analysis of data from the EURAP pregnancy and epilepsy register. Lancet Neurol 2011; 10: $609-17$ 
6. Isojärvi JI, Taubøll E, Herzog AG. Effect of antiepileptic drugs on reproductive endocrine function in individuals with epilepsy. CNS Drugs 2005; 19: 207-23.

7. Isojärvi JI, Laatikainen TJ, Pakarinen AJ et al. Polycystic ovaries and hyperandrogenism in women taking valproate for epilepsy. N Engl J Med 1993; 329: 1383-8.

8. Pickrell WO, Lacey AS, Thomas RH et al. Weight change associated with antiepileptic drugs. J Neurol Neurosurg Psychiatry 2013; 84: 796-9.

9. Nakken KO, Taubøll E. Bone loss associated with use of antiepileptic drugs. Expert Opin Drug Saf 2010; 9: 561-71

10. Koenig SA, Buesing D, Longin E et al. Valproic acid-induced hepatopathy: nine new fatalities in Germany from 1994 to 2003. Epilepsia 2006: 47: 2027-31.

11. Mattson RH, Cramer JA, McCutchen CB. Barbiturate-related connective tissue disorders. Arch Intern Med 1989: 149: 911-4

12. Ley M, Principe A, Jiménez-Conde J et al. Assessing long-term effects of eslicarbazepine acetate on lipid metabolism profile, sodium values and liver function tests. Epilepsy Res 2015; 115: $147-52$

13. Lewis C, Deshpande A, Tesar GE et al. Valproateinduced hyperammonemic encephalopathy: a brief review. Curr Med Res Opin 2012; 28: 1039-42.

14. Marson AG, Al-Kharusi AM, Alwaidh $\mathrm{M}$ et al. The SANAD study of effectiveness of carbamazepine, gabapentin, lamotrigine, oxcarbazepine, or topiramate for treatment of partial epilepsy: an unblinded randomised controlled trial. Lancet 2007; 369: 1000-15.

15. Gilliam F. The impact of epilepsy on subjective health status. Curr Neurol Neurosci Rep 2003; 3: $357-62$.

Mottatt 20.2. 2015, første revisjon innsendt 25.9. 2015, godkjent 5.1. 2016. Redaktør: Liv-Ellen Vangsnes. 